\title{
REVIEW
}

\section{Alzheimer's disease risk alleles in TREM2 illuminate innate immunity in Alzheimer's disease}

Todd E Golde*, Wolfgang J Streit and Paramita Chakrabarty

\begin{abstract}
Genetic studies have provided the best evidence for cause and effect relationships in Alzheimer's disease (AD). Indeed, the identification of deterministic mutations in the APP, PSEN1 and PSEN2 genes and subsequent preclinical studies linking these mutations to alterations in $A \beta$ production and aggregation have provided pivotal support for the amyloid cascade hypothesis. In addition, genetic, pathologic and biological studies of APOE have also indicated that the genetic risk for AD associated with APOE4 can be attributed, at least in part, to its pro-amyloidogenic effect on $A \beta$. In recent years a number of SNPs that show unequivocal genomewide association with AD risk have implicated novel genetic loci as modifiers of AD risk. However, the functional implications of these genetic associations are largely unknown. For almost all of these associations, the functional variants have not been identified. Very recently, two large consortiums demonstrated that rare variants in the triggering receptor expressed on myeloid cells 2 (TREM2) gene confer significant risk for AD. TREM2 is a type 1 membrane receptor protein primarily expressed on microglia in the central nervous system that has been shown to regulate phagocytosis and activation of monocytes. Previously it had been shown that homozygous loss of function mutations in TREM2 cause polycystic lipomembranous osteodysplasia with sclerosing leukoencephalopathy (PLOSL, Nasu Hakola disease) and also a pure form of early-onset dementia. The association of TREM 2 variants with $A D$ brings innate immune signaling into the light, affirming innate immunity's role as a significant factor in AD pathogenesis.
\end{abstract}

\footnotetext{
*Correspondence: tgolde@ufl.edu
}

Center for Translational Research in Neurodegenerative Disease, Department of Neuroscience, McKnight Brain Institute, College of Medicine, University of Florida, Gainesville, FL 32610, USA

\section{Introduction: Alzheimer's disease is not just a disease of neurons}

Neurodegenerative proteinopathies are not solely diseases of neurons but brain disorders in which there is altered function of neurons, astrocytes, microglia and possibly other cells (for example, oligodendrocytes, endothelial cells, and even peripheral immune cells that survey the central nervous system) [1,2]. Indeed, invariant pathological features of Alzheimer's disease (AD) as well as other neurodegenerative disorders are marked alterations in both astrocytes and microglia, reflecting underlying alterations in innate immune activation states within the brain. Innate immune signaling is thought to be altered early in AD, but is also skewed towards an activated state during human brain aging in the absence of a triggering proteinopathy $[3,4]$. Experimental studies in AD mouse models also show that manipulating innate immune pathways can have positive or negative effects on proteostasis (for example, tau and amyloid $\beta$ (A $\beta$ ) pathology), cognition and neurodegeneration [5].

Despite fairly intensive investigation, the precise role of innate immunity in $\mathrm{AD}$ and other neurodegenerative disorders remains enigmatic. Collectively, preclinical, epidemiologic and clinical studies reveal a somewhat conflicted literature. Whereas some studies would suggest that dampening innate immunity would be beneficial, others suggest that promoting innate immune activation would be beneficial $[5,6]$. Moreover, from a conceptual point of view innate immunity could be placed into the AD pathological cascade at many different places: as a trigger, a consequence, a modifier of progression or some combination of these [7]. Nevertheless, as there are numerous approved therapies targeting innate immune signaling pathways (for example, anti-tumor necrosis factor- $\alpha$, IL-6, IL-17 and IL-1 therapies) [8] as well as preclinical proof of concept studies for many innate immune targets, many investigators have been attracted by the potential to identify immunological targets for $\mathrm{AD}$ that could leverage therapies currently being developed for systemic immune disorders. 


\section{TREM2 variants are associated with Alzheimer's disease risk}

Recently, the unequivocal associations of SNPs within genetic loci that encode genes that function in innate immunity have added genetic support to the notion that innate immunity may have a significant role in AD. Variants in $C R 1$ and $C L U$, which play roles in the complement system, repeatedly show significant genetic associations with $\mathrm{AD}$ [9-13] whereas other genes (CD33, $M S 4 A 6 A, M S 4 A 4 E, A B C A 7, C D 2 A P)$ with either established or likely roles in innate immune function are also implicated as AD risk loci [12-15]. In addition, there appears to be a significant overrepresentation of association within genetic loci that encode innate immune genes $[16,17]$. However, as with the majority of genetic associations with $\mathrm{AD}$, the functional variants within these loci are unknown; thus, it is even premature to definitively conclude that such association reflects a functional variant that impacts function or expression of the encoded innate immune gene or alternatively alters a neighboring gene or non-coding RNA. In addition, the overall $\mathrm{AD}$ genetic risk or protection associated with these loci is small. Although if functional variants within these loci are definitively identified, it is possible that the risk associated with such rare functional variants could be much more significant.

Because of these issues, it has been challenging to experimentally assess the biological underpinnings of the potential genetic link between these novel loci and AD. However, recent studies have demonstrated that rare coding variants in triggering receptor expressed on myeloid cells 2 (TREM2), a known regulator of microglial activation and phagocytosis, confer substantial risk for AD $[18,19]$. TREM2 is highly expressed on microglia, as well as osteoclasts, dendritic cells and macrophages. It is a type 1 transmembrane glycoprotein that binds poorly characterized ligands (for example, bacteria, cell debris, and an astrocytoma cell-line), and, upon ligand binding, signals through DAP12 (TYROBP), an immunoreceptor tyrosine-based activation motif (ITAM)-containing transmembrane adaptor protein, and the SYK kinases that interact with the ITAM domain of DAP12 [20-22]. Since the cytoplasmic domain of TREM2 by itself has no intrinsic signaling capacity, it relies on DAP12 for signal transduction [23]. Homozygous, loss of function mutations in both TREM2 and DAP12 are known causes of polycystic lipomembranous osteodysplasia with sclerosing leukoencephalopathy (PLOSL), which is also known as Nasu Hakola disease [24-27]. By inference, one would expect that variants that reduce DAP12 function (and possibly other downstream signaling molecules) might also confer risk for $\mathrm{AD}$ if they result in partial but not complete loss of function. Notably, other homozygous mutations in TREM2 (T66M, Y38C, Q33X) have been associated with dementia without bone cysts $[19,28]$. Though the clinical presentation of these subjects is consistent with PLOSL without bone involvement, postmortem brain pathology has not been reported.

Association of TREM2 with AD was initially shown using whole exome sequencing and whole genome sequencing $[18,19]$. In these studies, the most definitive risk for $\mathrm{AD}$ was associated with the heterozygous $\mathrm{R} 47 \mathrm{H}$ variant (rs75932628-T) of TREM2. Notably, the risk associated with this allele was strong with odds ratios in the initial two studies of 2.9 (95\% confidence interval 2.16 to 3.91) [18] and 4.5 (95\% confidence interval 1.7 to 11.9 ) [19]; thus, roughly equivalent to the risk associated with one APOE4 allele [29]. In addition, a number of other variants in TREM2 were present in $\mathrm{AD}$ patients but not controls, with one variant (D87N) showing significant association with disease [30]. Since these initial publications, two other publications have confirmed the risk associated with the $\mathrm{R} 47 \mathrm{H}$ variant to other populations and even early onset AD [31,32]. Thus, TREM2 represents the first gene within the innate immune signaling pathway for which functional variants show association with AD risk.

On the surface these exciting genetic findings appear to provide the first rapidly tractable genetic association between a gene that is known to regulate innate immunity and AD. However, some caution is warranted, as inferring both functional effects of these variants on TREM2 and the relationship to the AD pathological cascade is, at this point, largely speculative. The TREM2 $\mathrm{R} 47 \mathrm{H}$ and other variants more tentatively associated with $\mathrm{AD}$ risk are all located within the extracellular immunoglobulin-like domain of TREM2. Thus, similar to the mutations in the same region that cause PLOSL, it is hypothesized that the variants in TREM2 associated with $\mathrm{AD}$ cause loss of function or partial loss of function, reducing ligand binding and downstream signaling $[18,30]$. It is also possible that they result in nonsensemediated RNA decay and reduce TREM2 levels. A soluble form of TREM2 and other variants have also been identified that could influence the function, level, or both of TREM2 [33,34]. Thus, TREM2 could have non-cell autonomous actions. In addition, as the TREM2 ectodomain can be shed [34], it has been speculated that TREM2 may undergo regulated intramembrane proteolysis with the membrane stub being further processed by $\gamma$-secretase, and it is possible that these cleavages could be altered by these mutations. Finally, although the initial focus of TREM2 in AD will likely focus on its role in microglial activation, it is important to consider other possible functional roles of TREM2 on cells other than microglia within the central nervous system and also in regulating peripheral immune cell entry and activity in the brain. 
Given that Trem2 activation has been shown to enhance phagocytosis and suppress cytokine production in mice [22,35], TREM2 could have very complex biological effects relevant to regulation of $A \beta$ deposition as well as innate immune responses triggered by $A \beta$ accumulation, such as regulation of cell-to-cell transmission of tau, induction of other intracellular proteinopathies and neurodegeneration. Trem 2 has been shown to be present in plaque-associated microglia in young and aged APP transgenic mice, presumably as a response to $A \beta$ pathology $[19,36,37]$. Thus, TREM2 variants could influence age of onset, progression of disease, or both. However, at this point much more data are needed to understand how AD-associated variants influence TREM2 function, and how that variation in function alters factors relevant to $\mathrm{AD}$ pathogenesis. Notably, postmortem pathological phenotypes of brains from D87N and $\mathrm{R} 47 \mathrm{H}$ carriers were well within the normal spectrum of pathologies noted in typical AD [19]. To date, there have been no reports of distinguishing clinical phenotypes in $\mathrm{R} 47 \mathrm{H}$ carriers.

\section{Putting TREM2 in context}

Innate immune signaling in the brain is highly complex and may reflect varying states of immune activation and suppression in both health and disease. A potentially useful framework to classify innate immune activation states that was adopted from studies of peripheral macrophages has been to describe microglial phenotype as a classic activation (M1) or alternative activation (M2) state [38-40]. However, though this classification system is a useful framework, there is growing recognition that a rigid application of these dichotomous microglial phenotypes may be too simplistic [6]. In general, M1 microglial phenotypes have been associated with neurotoxicity and M2 with a neuroprotective/neuro-remodeling role. Based on what we know about TREM2 functions in myeloid cells and the presumed loss of function effects of TREM2 variants associated with $\mathrm{AD}$, one could suggest that the genetic association of TREM2 with $\mathrm{AD}$ indicates that suppression of an M2-like neuroprotective microglial response with decreased phagocytosis and increased cytokine production might promote AD pathologies. However, a survey of published studies in the field suggests that a unified view of the role of innate immunity, microglial activation states and $\mathrm{AD}$ pathology is not feasible at this time $[5,6]$. For example, our data and that from other groups show that an M1-like pro-inflammatory microglial activation state protects from $A \beta$ pathology, whereas an M2-like alternative activation state can promote $A \beta$ pathology [41-49]. In contrast, others have reported that an $\mathrm{M} 2$-like microglial activation state protects from both $A \beta$ pathology and cognitive and synaptic dysfunction [50-56]. There is also evidence, albeit much more limited, that factors that might protect from $A \beta$ pathology might promote tau pathology and vice versa [57-60]. Like the preclinical data generated to date, epidemiologic and clinical data reveal a fairly conflicted literature on observational and clinical trial findings on non-steroidal anti-inflammatory drug (NSAID) use and AD [61-72]. Long-term NSAID use has been repeatedly shown to confer protection in epidemiologic studies, but clinical trials in AD patients with celecoxib and naproxen have not shown any benefit [73]. The Alzheimer's Disease Anti-inflammatory Prevention Trial (ADAPT) testing AD 'prevention' with naproxen and celecoxib was halted due to cardiovascular side-effects induced by naproxen; however, follow-up studies along with some post hoc analysis of this trial suggests that treatment effects could vary depending on underlying, clinically silent AD pathology at the time of trial enrollment [68-72]. Another intriguing observation relating to human NSAID use and AD was a report showing that naproxen use was associated with increased post-mortem brain $A \beta$ pathology [74].

A final factor that must be taken into account when trying to understand the role of the innate immune system in the AD brain is the recent data that indicate widespread upregulation of innate immune gene expression in the aging human brain [4]. At this point, it is unclear how this underlying age-related 'skewing' of the innate immune response towards an activated state affects development and progression of AD. By inference from other chronic inflammatory conditions, one could argue that a chronic pro-inflammatory environment would be harmful, and could either directly promote ageassociated decline in function, sensitize the brain to a second insult or even trigger a proteinopathy. Alternatively, one could argue that a proinflammatory environment might actually help to remodel the brain and protect it from proteinopathies by promoting the removal of misfolded proteins and danger signals released by degenerating cells. In actuality, the effects may be quite complex, with the balance between positive and negative effects of innate immune activation on proteostasis and neurodegeneration in AD contextually dependent on the nature, timing, duration, and strength of the specific signals. Furthermore, immune 'manipulations' probably have more complex effects on innate immune activation and other factors that could influence $\mathrm{AD}$ pathologies than what are currently being surveyed, and thus a broader approach may be needed to understand how manipulations of a given innate immune pathway impacts AD.

While there has been previous interest in therapeutic strategies targeting inflammation and innate immunity in $\mathrm{AD}$, probably because of the conflicted preclinical and clinical data, there has been limited activity relating to 
development of novel innate immune targeting therapies in $\mathrm{AD}$. If future studies can tie the action of ADassociated TREM2 variants to changes in microglial function that influence AD-relevant phenotypes, there will be direct genetic evidence that alterations in innate immune responses confer risk for AD. Such data will likely spur renewed interest in development of innate immune modulatory strategies for AD. Indeed, as opposed to therapies targeting the protein aggregates that are most likely to be effective as prophylactics, therapies modulating innate immune targets could be predicted to have efficacy during later disease stages. Given our current understanding of TREM2 function, as well as the large body of data showing that innate immunity can alter proteostasis and neurodegeneration, it is likely that many different novel therapeutic approaches may arise from these studies. Some of these approaches may directly target TREM2 whereas others might target parallel pathways that also regulate microglial activation.

Another intriguing aspect of these new data is that they represent another example of how variants within a genetic locus can confer risk for or cause one type of neurodegenerative disorder when present in a heterozygous state and cause a distinct disorder in the compound heterozygous or homozygous state. Other known examples are i) heterozygous progranulin $(P R G N)$ mutations resulting in frontal temporal lobar degeneration and homozygous or compound heterozygous PRGN mutants causing neuronal ceroid lipofuscinosis [75,76], and ii) heterozygous glucocerebrosidase (GBA) mutations associated with risk for Parkinson's disease and homozygous or compound heterozygous GBA mutations causing Gaucher's disease [77,78]. Why variants or mutations produce these different neurological phenotypes in the heterozygous versus the compound heterozygous or homozygous states is quite enigmatic, but certainly an area worthy of further study.

\section{Conclusions}

With the spotlight firmly placed on TREM2's role in AD, research advances will likely be quite rapid, and the emerging data will likely enable a more unified understanding of the function of innate immune signaling in AD. Although the possibility of harnessing TREM2 for therapeutic benefit is tempting, until we learn more about the functionality and regulation of this protein in the brain, it is challenging to envision how one would target TREM2 in AD. More generally, future genomic studies aimed at identifying rare functional variants in i) innate immune loci already associated with $\mathrm{AD}$ through genome-wide association studies or ii) innate immune genes shown to modulate relevant diseaseassociated pathology could provide a steady stream of new rare functional variants in innate immune genes that might impact AD risk. Indeed, it is important to note that TREM2 never reached genome-wide significance in the published genome-wide association studies. Thus, combining biological inference with whole exome or whole genome sequencing strategies is likely to yield a treasure chest of novel genetic variants in innate immune signaling factors that influence risk for AD. Hopefully, these will not only tell us more about AD pathogenesis, but will also reveal tractable therapeutic targets.

\section{Abbreviations}

$A \beta$, amyloid $\beta ; A D$, Alzheimer's disease; IL, interleukin; ITAM, immunoreceptor tyrosine-based activation motif; NSAID, non-steroidal anti-inflammatory drug; PLOSL, polycystic lipomembranous osteodysplasia with sclerosing leukoencephalopathy; SNP single-nucleotide polymorphism; TREM2, triggering receptor expressed on myeloid cells 2 .

\section{Competing interests}

The authors declare that they have no competing interests.

\section{Acknowledgments}

Supported by RO1 AG018454 from the NIH/NIA (TEG), The Ellison Medical Foundation (TEG), and the BrightFocus Foundation (formerly AHAF) (PC). We also wish to thank the Cooper family of Indialantic, FL for their support of dementia research.

\section{Published: 21 May 2013}

\section{References}

1. Ransohoff RM, Brown MA: Innate immunity in the central nervous system. J Clin Invest 2012, 122:1164-1171.

2. Aguzzi A, Barres BA, Bennett ML: Microglia: scapegoat, saboteur, or something else? Science 2013, 339:156-161.

3. Akiyama H, Barger S, Barnum S, Bradt B, Bauer J, Cole GM, Cooper NR, Eikelenboom P, Emmerling M, Fiebich BL, Finch CE, Frautschy S, Griffin WS, Hampel H, Hull M, Landreth G, Lue L, Mrak R, Mackenzie IR, McGeer PL, O'Banion MK, Pachter J, Pasinetti G, Plata-Salaman C, Rogers J, Rydel R, Shen Y, Streit W, Strohmeyer R, Tooyoma I, et al.: Inflammation and Alzheimer's disease. Neurobiol Aging 2000, 21:383-421.

4. Cribbs DH, Berchtold NC, Perreau V, Coleman PD, Rogers J, Tenner AJ, Cotman $C W$ : Extensive innate immune gene activation accompanies brain aging, increasing vulnerability to cognitive decline and neurodegeneration: a microarray study. J Neuroinflammation 2012, 9:179.

5. Czirr E, Wyss-Coray T: The immunology of neurodegeneration. J Clin Invest 2012, 122:1156-1163.

6. Town T, Nikolic V, Tan J: The microglial "activation" continuum: from innate to adaptive responses. J Neuroinflammation 2005, 2:24.

7. Wyss-Coray T: Inflammation in Alzheimer disease: driving force, bystander or beneficial response? Nat Med 2006, 12:1005-1015.

8. Taylor PC, Feldmann M: Anti-TNF biologic agents: still the therapy of choice for rheumatoid arthritis. Nat Rev Rheumato/ 2009, 5:578-582.

9. Allen M, Zou F, Chai HS, Younkin CS, Crook J, Pankratz VS, Carrasquillo MM, Rowley CN, Nair AA, Middha S, Maharjan S, Nguyen T, Ma L, Malphrus KG, Palusak R, Lincoln S, Bisceglio G, Georgescu C, Schultz D, Rakhshan F, Kolbert CP, Jen J, Haines JL, Mayeux R, Pericak-Vance MA, Farrer LA, Schellenberg GD; Alzheimer's Disease Genetics Consortium, Petersen RC, Graff-Radford NR, et al:: Novel late-onset Alzheimer disease loci variants associate with brain gene expression. Neurology 2012, 79:221-228

10. Belbin O, Carrasquillo MM, Crump M, Culley OJ, Hunter TA, Ma L, Bisceglio G, Zou F, Allen M, Dickson DW, Graff-Radford NR, Petersen RC, Morgan K, Younkin SG: Investigation of 15 of the top candidate genes for late-onset Alzheimer's disease. Hum Genet 2011, 129:273-282.

11. Corneveaux JJ, Myers AJ, Allen AN, Pruzin JJ, Ramirez M, Engel A, Nalls MA Chen K, Lee W, Chewning K, Villa SE, Meechoovet HB, Gerber JD, Frost D, Benson HL, O'Reilly S, Chibnik LB, Shulman JM, Singleton AB, Craig DW, Van Keuren-Jensen KR, Dunckley T, Bennett DA, De Jager PL, Heward C, Hardy J, Reiman EM, Huentelman MJ: Association of CR1, CLU and PICALM with Alzheimer's disease in a cohort of clinically characterized and 
neuropathologically verified individuals. Hum Mol Genet 2010, 19:3295-3301

12. Lambert JC, Heath S, Even G, Campion D, Sleegers K, Hiltunen M, Combarros O, Zelenika D, Bullido MJ, Tavernier B, Letenneur L, Bettens K, Berr C, Pasquier F, Fiévet N, Barberger-Gateau P, Engelborghs S, De Deyn P, Mateo I, Franck A, Helisalmi S, Porcellini E, Hanon O; European Alzheimer's Disease Initiative Investigators, de Pancorbo MM, Lendon C, Dufouil C, Jaillard C, Leveillard T, Alvarez V, et al:: Genome-wide association study identifies variants at CLU and CR1 associated with Alzheimer's disease. Nat Genet 2009, 41:1094-1099

13. Harold D, Abraham R, Hollingworth P, Sims R, Gerrish A, Hamshere ML, Pahwa JS, Moskvina V, Dowzell K, Williams A, Jones N, Thomas C, Stretton A, Morgan AR, Lovestone S, Powell J, Proitsi P, Lupton MK, Brayne C, Rubinsztein DC, Gill M, Lawlor B, Lynch A, Morgan K, Brown KS, Passmore PA, Craig D, McGuinness B, Todd S, Holmes C, et al: Genome-wide association study identifies variants at CLU and PICALM associated with Alzheimer's disease. Nat Genet 2009, 41:1088-1093.

14. Bertram L, McQueen MB, Mullin K, Blacker D, Tanzi RE: Systematic metaanalyses of Alzheimer disease genetic association studies: the AlzGene database. Nat Genet 2007, 39:17-23.

15. Hollingworth P, Harold D, Sims R, Gerrish A, Lambert JC, Carrasquillo MM, Abraham R, Hamshere ML, Pahwa JS, Moskvina V, Dowzell K, Jones N, Stretton A, Thomas C, Richards A, Ivanov D, Widdowson C, Chapman J, Lovestone S, Powell J, Proitsi P, Lupton MK, Brayne C, Rubinsztein DC, Gill M, Lawlor B, Lynch A, Brown KS, Passmore PA, Craig D, et al.: Common variants at ABCA7, MS4A6A/MS4A4E, EPHA1, CD33 and CD2AP are associated with Alzheimer's disease. Nat Genet 2011, 43:429-435.

16. Lambert JC, Grenier-Boley B, Chouraki V, Heath S, Zelenika D, Fievet N, Hannequin D, Pasquier F, Hanon O, Brice A, Epelbaum J, Berr C, Dartigues JF, Tzourio C, Campion D, Lathrop M, Amouyel P: Implication of the immune system in Alzheimer's disease: evidence from genome-wide pathway analysis. J Alzheimers Dis 2010, 20:1107-1118.

17. Jones L, Holmans PA, Hamshere ML, Harold D, Moskvina V, Ivanov D, Pocklington A, Abraham R, Hollingworth P, Sims R, Gerrish A, Pahwa JS, Jones N, Stretton A, Morgan AR, Lovestone S, Powell J, Proitsi P, Lupton MK, Brayne C, Rubinsztein DC, Gill M, Lawlor B, Lynch A, Morgan K, Brown KS, Passmore PA, Craig D, McGuinness B, Todd S, et al: Genetic evidence implicates the immune system and cholesterol metabolism in the aetiology of Alzheimer's disease. PLoS One 2010, 5:e13950.

18. Jonsson T, Stefansson H, Steinberg S, Jonsdottir I, Jonsson PV, Snaedal J, Bjornsson S, Huttenlocher J, Levey Al, Lah JJ, Rujescu D, Hampel H, Giegling I, Andreassen OA, Engedal K, Ulstein I, Djurovic S, Ibrahim-Verbaas C, Hofman A, I kram MA, van Duijn CM, Thorsteinsdottir U, Kong A, Stefansson K: Variant of TREM2 associated with the risk of Alzheimer's disease. N Engl J Med 2013, 368:107-116.

19. Guerreiro R, Wojtas A, Bras J, Carrasquillo M, Rogaeva E, Majounie E, Cruchaga C, Sassi C, Kauwe JS, Younkin S, Hazrati L, Collinge J, Pocock J, Lashley T, Williams J, Lambert JC, Amouyel P, Goate A, Rademakers R, Morgan K, Powell J, St George-Hyslop P, Singleton A, Hardy J; Alzheimer Genetic Analysis Group: TREM2 variants in Alzheimer's disease. N Engl J Med 2012, 368:117-127.

20. Neumann H, Takahashi K: Essential role of the microglial triggering receptor expressed on myeloid cells-2 (TREM2) for central nervous tissue immune homeostasis. J Neuroimmunol 2007, 184:92-99.

21. Takahashi K, Prinz M, Stagi M, Chechneva O, Neumann H: TREM2-transduced myeloid precursors mediate nervous tissue debris clearance and facilitate recovery in an animal model of multiple sclerosis. PLoS Med 2007, 4:e124.

22. Turnbull IR, Gilfillan S, Cella M, Aoshi T, Miller M, Piccio L, Hernandez M, Colonna M: Cutting edge: TREM-2 attenuates macrophage activation. $\mathrm{J}$ Immunol 2006, 177:3520-3524

23. Klesney-Tait J, Turnbull IR, Colonna M: The TREM receptor family and signal integration. Nat Immunol 2006, 7:1266-1273.

24. Paloneva J, Manninen T, Christman G, Hovanes K, Mandelin J, Adolfsson R, Bianchin M, Bird T, Miranda R, Salmaggi A, Tranebjaerg L, Konttinen Y, Peltonen $L$ : Mutations in two genes encoding different subunits of a receptor signaling complex result in an identical disease phenotype. Am J Hum Genet 2002, 71:656-662

25. Paloneva J, Mandelin J, Kiialainen A, Bohling T, Prudlo J, Hakola P, Haltia M, Konttinen YT, Peltonen L: DAP12/TREM2 deficiency results in impaired osteoclast differentiation and osteoporotic features. J Exp Med 2003, 198:669-675.

26. Klünemann HH, Ridha BH, Magy L, Wherrett JR, Hemelsoet DM, Keen RW,
De Bleecker JL, Rossor MN, Marienhagen J, Klein HE, Peltonen L, Paloneva J: The genetic causes of basal ganglia calcification, dementia, and bone cysts: DAP12 and TREM2. Neurology 2005, 64:1502-1507.

27. Kondo T, Takahashi K, Kohara N, Takahashi Y, Hayashi S, Takahashi H, Matsuo H, Yamazaki M, Inoue K, Miyamoto K, Yamamura T: Heterogeneity of presenile dementia with bone cysts (Nasu-Hakola disease): three genetic forms. Neurology 2002, 59:1105-1107.

28. Chouery E, Delague V, Bergougnoux A, Koussa S, Serre JL, Megarbane A: Mutations in TREM2 lead to pure early-onset dementia without bone cysts. Hum Mutat 2008, 29:E194-204.

29. Saunders AM, Strittmatter WJ, Schmechel D, George-Hyslop PHS, PericakVance MA, Joo SH, Rosi BL, Gusella JF, Crapper-MacLachlan DR, Alberts MJ, et al:: Association of apolipoprotein E allele $\varepsilon 4$ with late-onset familial and sporadic Alzheimer's disease. Neurology 1993, 43:1467-1472.

30. Guerreiro RJ, Lohmann E, Brás JM, Gibbs JR, Rohrer JD, Gurunlian N, Dursun B, Bilgic B, Hanagasi H, Gurvit H, Emre M, Singleton A, Hardy J: Using exome sequencing to reveal mutations in TREM2 presenting as a frontotemporal dementia-like syndrome without bone involvement. Arch Neurol 2012:1-7.

31. Pottier C, Wallon D, Rousseau S, Rovelet-Lecrux A, Richard AC, Rollin-Sillaire A Frebourg T, Campion D, Hannequin D: TREM2 R47H variant as a risk factor for early-onset Alzheimer's disease. J Alzheimers Dis 2013, 35:45-49.

32. Benitez BA, Cooper B, Pastor P, Jin SC, Lorenzo E, Cervantes S, Cruchaga C: TREM2 is associated with the risk of Alzheimer's disease in Spanish population. Neurobiol Aging 2013, 34:1711.e15-17.

33. Yoon SH, Lee YD, Ha J, Lee Y, Kim HH: TLT-1s, alternative transcripts of triggering receptor expressed on myeloid cell-like transcript-1 (TLT-1), Inhibits the triggering receptor expressed on myeloid cell-2 (TREM-2)mediated signaling pathway during osteoclastogenesis. J Biol Chem 2012, 287:29620-29626.

34. Piccio L, Buonsanti C, Cella M, Tassi I, Schmidt RE, Fenoglio C, Rinker I 2nd, Naismith RT, Panina-Bordignon P, Passini N, Galimberti D, Scarpini E, Colonna M, Cross AH: Identification of soluble TREM-2 in the cerebrospinal fluid and its association with multiple sclerosis and CNS inflammation. Brain 2008, 131:3081-3091.

35. Hamerman JA, Jarjoura JR, Humphrey MB, Nakamura MC, Seaman WE, Lanier $L L$ : Cutting edge: inhibition of TLR and FcR responses in macrophages by triggering receptor expressed on myeloid cells (TREM)-2 and DAP12. J Immunol 2006, 177:2051-2055.

36. Frank S, Burbach GJ, Bonin M, Walter M, Streit W, Bechmann I, Deller T: TREM2 is upregulated in amyloid plaque-associated microglia in aged APP23 transgenic mice. Glia 2008, 56:1438-1447.

37. Melchior B, Garcia AE, Hsiung BK, Lo KM, Doose JM, Thrash JC, Stalder AK, Staufenbiel M, Neumann H, Carson MJ: Dual induction of TREM2 and tolerance-related transcript, Tmem176b, in amyloid transgenic mice: implications for vaccine-based therapies for Alzheimer's disease. ASN Neuro 2010, 2:e00037.

38. Kigerl KA, Gensel JC, Ankeny DP, Alexander JK, Donnelly DJ, Popovich PG: Identification of two distinct macrophage subsets with divergent effects causing either neurotoxicity or regeneration in the injured mouse spinal cord. J Neurosci 2009, 29:13435-13444.

39. Mantovani A, Sica A, Locati M: Macrophage polarization comes of age. Immunity 2005, 23:344-346.

40. Ransohoff RM, Perry VH: Microglial physiology: unique stimuli, specialized responses. Annu Rev Immunol 2009, 27:1 19-145.

41. Chavez-Gutierrez L, Tolia A, Maes E, LiT, Wong PC, de Strooper B: Glu(332) in the Nicastrin ectodomain is essential for gamma-secretase complex maturation but not for its activity. J Biol Chem 2008, 283:20096-20105.

42. Chakrabarty P, Jansen-West K, Beccard A, Ceballos-Diaz C, Levites Y, Verbeeck C, Zubair AC, Dickson D, Golde TE, Das P: Massive gliosis induced by interleukin-6 suppresses Abeta deposition in vivo: evidence against inflammation as a driving force for amyloid deposition. FASEB J 2010, 24:548-559.

43. Chakrabarty P, Herring A, Ceballos-Diaz C, Das P, Golde TE: Hippocampal expression of murine TNFalpha results in attenuation of amyloid deposition in vivo. Mol Neurodegener 2011, 6:16.

44. Chakrabarty P, Ceballos-Diaz C, Beccard A, Janus C, Dickson D, Golde TE, Das P: IFN-gamma promotes complement expression and attenuates amyloid plaque deposition in amyloid beta precursor protein transgenic mice. J Immunol 2010, 184:5333-5343.

45. Song M, Jin J, Lim JE, Kou J, Pattanayak A, Rehman JA, Kim HD, Tahara K, Lalonde R, Fukuchi K: TLR4 mutation reduces microglial activation, 
increases Abeta deposits and exacerbates cognitive deficits in a mouse model of Alzheimer's disease. J Neuroinflammation 2011, 8:92.

46. Herber DL, Mercer M, Roth LM, Symmonds K, Maloney J, Wilson N, Freeman MJ, Morgan D, Gordon MN: Microglial activation is required for Abeta clearance after intracranial injection of lipopolysaccharide in APP transgenic mice. J Neuroimmune Pharmacol 2007, 2:222-231.

47. Michaud JP, Hallé M, Lampron A, Thériault $P$, Préfontaine $P$, Filali M, TriboutJover P, Lanteigne AM, Jodoin R, Cluff C, Brichard V, Palmantier R, Pilorget A, Larocque D, Rivest S: Toll-like receptor 4 stimulation with the detoxified ligand monophosphoryl lipid A improves Alzheimer's disease-related pathology. Proc Natl Acad Sci U S A 2013, 110:1941-1946.

48. Boissonneault V, Filali M, Lessard M, Relton J, Wong G, Rivest S: Powerfu beneficial effects of macrophage colony-stimulating factor on betaamyloid deposition and cognitive impairment in Alzheimer's disease. Brain 2009, 132:1078-1092.

49. Chakrabarty P, Tianbai L, Herring A, Ceballos-Diaz C, Das P, Golde TE: Hippocampal expression of murine IL-4 results in exacerbation of amyloid deposition. Mol Neurodegener 2012, 7:36.

50. Mandrekar-Colucci S, Landreth GE: Nuclear receptors as therapeutic targets for Alzheimer's disease. Expert Opin Ther Targets 2011, 15:1085-1097.

51. Reed-Geaghan EG, Reed QW, Cramer PE, Landreth GE: Deletion of CD14 attenuates Alzheimer's disease pathology by influencing the brain's inflammatory milieu. J Neurosci 2010, 30:15369-15373.

52. Reed-Geaghan EG, Savage JC, Hise AG, Landreth GE: CD14 and toll-like receptors 2 and 4 are required for fibrillar A\{beta\}-stimulated microglia activation. J Neurosci 2009, 29:1 1982-11992.

53. Liu S, Liu Y, Hao W, Wolf L, Kiliaan AJ, Penke B, Rübe CE, Walter J, Heneka MT, Hartmann T, Menger MD, Fassbender K: TLR2 is a primary receptor for Alzheimer's amyloid beta peptide to trigger neuroinflammatory activation. J Immuno/ 2012, 188:1098-1107

54. Heneka MT, Kummer MP, Stutz A, Delekate A, Schwartz S, Vieira-Saecker A Griep A, Axt D, Remus A, Tzeng TC, Gelpi E, Halle A, Korte M, Latz E, Golenbock DT: NLRP3 is activated in Alzheimer's disease and contributes to pathology in APP/PS1 mice. Nature 2012, 493:674-678

55. Kummer MP, Vogl T, Axt D, Griep A, Vieira-Saecker A, Jessen F, Gelpi E, Roth J, Heneka MT: Mrp14 deficiency ameliorates amyloid beta burden by increasing microglial phagocytosis and modulation of amyloid precursor protein processing. J Neurosci 2012, 32:17824-17829.

56. Yamanaka M, Ishikawa T, Griep A, Axt D, Kummer MP, Heneka MT: PPARgamma/RXRalpha-induced and CD36-mediated microglial amyloidbeta phagocytosis results in cognitive improvement in amyloid precursor protein/presenilin 1 mice. J Neurosci 2012, 32:17321-17331.

57. Bhaskar K, Konerth M, Kokiko-Cochran ON, Cardona A, Ransohoff RM, Lamb $B T$ : Regulation of tau pathology by the microglial fractalkine receptor. Neuron 2010, 68:19-31.

58. Lee DC, Rizer J, Selenica ML, Reid P, Kraft C, Johnson A, Blair L, Gordon MN, Dickey CA, Morgan D: LPS- induced inflammation exacerbates phosphotau pathology in rTg4510 mice. J Neuroinflammation 2010, 7:56.

59. Britschai M, Takeda-Uchimura Y, Rockenstein E, Johns H, Masliah E, Wyss-Coray T: Deficiency of terminal complement pathway inhibitor promotes neuronal tau pathology and degeneration in mice. J Neuroinflammation 2012, 9:220.

60. Nash KR, Lee DC, Hunt JB Jr, Morganti JM, Selenica ML, Moran P, Reid P, Brownlow M, Guang-Yu Yang C, Savalia M, Gemma C, Bickford PC, Gordon MN, Morgan D: Fractalkine overexpression suppresses tau pathology in a mouse model of tauopathy. Neurobiol Aging 2013, 34:1540-1548.

61. Breitner JC: Inflammatory processes and antiinflammatory drugs in Alzheimer's disease: a current appraisal. Neurobiol Aging 1996, 17:789-794.

62. McGeer PL, Schulzer M, McGeer EG: Arthritis and anti-inflammatory agents as possible protective factors for Alzheimer's disease: a review of 17 epidemiologic studies [see comments]. Neurology 1996, 47:425-432.
63. in 't Veld BA, Launer LJ, Hoes AW, Ott A, Hofman A, Breteler MM, Stricker BH: NSAIDs and incident Alzheimer's disease. The Rotterdam Study [see comments]. Neurobiol Aging 1998, 19:607-611.

64. Anthony JC, Breitner JC, Zandi PP, Meyer MR, Jurasova I, Norton MC, Stone SV: Reduced prevalence of $\mathrm{AD}$ in users of NSAIDs and $\mathrm{H} 2$ receptor antagonists: the Cache County study. Neurology 2000, 54:2066-2071.

65. Combs CK, Johnson DE, Karlo JC, Cannady SB, Landreth GE: Inflammatory mechanisms in Alzheimer's disease: inhibition of beta- amyloidstimulated proinflammatory responses and neurotoxicity by PPARgamma agonists. J Neurosci 2000, 20:558-567.

66. in t'Veld BA, Ruitenberg A, Hofman A, Launer $\sqcup$, van Duijn CM, Stijnen T, Breteler MM, Stricker BH: Nonsteroidal antiinflammatory drugs and the risk of Alzheimer's disease. N Engl J Med 2001, 345:1515-1521.

67. Aisen PS, Schafer KA, Grundman M, Pfeiffer E, Sano M, Davis KL, Farlow MR, Jin S, Thomas RG, Thal LJ: Effects of rofecoxib or naproxen vs placebo on Alzheimer disease progression: a randomized controlled trial. JAMA 2003, 289:2819-2826.

68. Breitner JC, Baker LD, Montine TJ, Meinert CL, Lyketsos CG, Ashe KH, Brandt J, Craft S, Evans DE, Green RC, Ismail MS, Martin BK, Mullan MJ, Sabbagh M, Tariot PN; ADAPT Research Group: Extended results of the Alzheimer's Disease Anti-inflammatory Prevention Trial. Alzheimers Dement 2011, 7:402-411.

69. Leoutsakos JM, Muthen BO, Breitner JC, Lyketsos CG: Effects of non-steroidal anti-inflammatory drug treatments on cognitive decline vary by phase of pre-clinical Alzheimer disease: findings from the randomized controlled Alzheimer's Disease Anti-inflammatory Prevention Trial. Int J Geriatr Psychiatry 2012, 27:364-374.

70. Meinert CL, MCCaffrey LD, Breitner JC: Alzheimer's Disease Anti-inflammatory Prevention Trial: design, methods, and baseline results. Alzheimers Dement 2009, 5:93-104.

71. Breitner J, Evans D, Lyketsos C, Martin B, Meinert C: ADAPT trial data. Am J Med 2007, 120:e3; author reply e5; discussion e7.

72. Breitner JC, Martin BK, Meinert CL: The suspension of treatments in ADAPT: concerns beyond the cardiovascular safety of celecoxib or naproxen. PLOS Clin Trials 2006, 1:e41

73. Zandi PP, Breitner JC: Do NSAIDs prevent Alzheimer's disease? And, if so, why? The epidemiological evidence. Neurobiol Aging 2001, 22:811-817.

74. Sonnen JA, Larson EB, Walker RL, Haneuse S, Crane PK, Gray SL, Breitner JC, Montine TJ: Nonsteroidal anti-inflammatory drugs are associated with increased neuritic plaques. Neurology 2010, 75:1203-1210.

75. Baker M, Mackenzie IR, Pickering-Brown SM, Gass J, Rademakers R, Lindholm C, Snowden J, Adamson J, Sadovnick AD, Rollinson S, Cannon A, Dwosh E, Neary D, Melquist S, Richardson A, Dickson D, Berger Z, Eriksen J, Robinson T, Zehr C, Dickey CA, Crook R, McGowan E, Mann D, Boeve B, Feldman H, Hutton M: Mutations in progranulin cause tau-negative frontotemporal dementia linked to chromosome 17. Nature 2006, 442:916-919.

76. Smith KR, Damiano J, Franceschetti S, Carpenter S, Canafoglia L, Morbin M, Rossi G, Pareyson D, Mole SE, Staropoli JF, Sims KB, Lewis J, Lin WL, Dickson DW, Dahl HH, Bahlo M, Berkovic SF: Strikingly different clinicopathological phenotypes determined by progranulin-mutation dosage. Am J Hum Genet 2012, 90:1102-1107.

77. Tayebi N, Callahan M, Madike V, Stubblefield BK, Orvisky E, Krasnewich D, Fillano JJ, Sidransky E: Gaucher disease and parkinsonism: a phenotypic and genotypic characterization. Mol Genet Metab 2001, 73:313-321.

78. Sidransky E, Lopez G: The link between the GBA gene and parkinsonism. Lancet Neurol 2012, 11:986-998.

doi:10.1186/alzrt178

Cite this article as: Golde TE, et al: Alzheimer's disease risk alleles in TREM2 illuminate innate immunity in Alzheimer's disease. Alzheimer's Research \& Therapy 2013, 5:24. 